\title{
Pollinizer Efficacy of Several 'Ingeborg' Pear Pollinizers in Hardanger, Norway, Examined Using Microsatellite Markers
}

\author{
Fuad Gasi \\ Faculty of Agriculture and Food Sciences, University of Sarajevo, Zmaja od \\ Bosne 8, 71000 Sarajevo, Bosnia and Herzegovina
}

Naris Pojskić

Institute for genetic engineering and biotechnology, University of Sarajevo, Laboratory for molecular genetics of natural resources, Zmaja od Bosne 8, Kampus, 71000 Sarajevo, Bosnia and Herzegovina

Mirsad Kurtovic

Faculty of Agriculture and Food Sciences, University of Sarajevo, Zmaja od Bosne 8, 71000 Sarajevo, Bosnia and Herzegovina

\section{Clive Kaiser}

Department of Horticulture, Oregon State University, 418 North Main Street, Milton Freewater, OR 97862

\section{Stein Harald Hjeltnes \\ Graminor, Hommelstadvegen 60, N-2322 Ridabu, Norway}

\author{
Milica Fotiric-Aksic \\ Faculty of Agriculture, University of Belgrade, Nemanjina 6, Belgrade, \\ Serbia

Mekjell Meland ${ }^{1}$
Norwegian Institute of Bioeconomy Research, Postbox 115, N-1432-Aas,
Norway

Additional index words. DNA, Pyrus communis, genetic diversity, seeds, paternity testing

Abstract. 'Ingeborg' is currently the main commercial pear cultivar grown in Norway. However, fruit set and subsequent yields of this cultivar have proven to be variable and overall low averaging 10-20 th.ha ${ }^{-1}$. Pear seeds found in 'Ingeborg' fruits are often underdeveloped, suggesting that incomplete fertilization might be a major cause of poor fruit set. In some years, sporadically unfavorable environmental conditions during and immediately after pollination in Hardanger district, western Norway, have resulted in poor fruit set of 'Ingeborg'. In this study, the pollinizer efficacy of several pollinizers, namely 'Clara Frijs', 'Herzogin Elsa', 'Anna', 'Colorée de Juillet', and 'Belle lucrative', from several orchards located in the Hardanger district was investigated using 12 microsatellite markers for two growing seasons (2014 and 2016). Pollinizer efficacy was estimated by genotyping 'Ingeborg', each individual pollinizer, as well as normally developed seeds from 'Ingeborg' fruit, and conducting gene assignment analyses to identify the pollen contribution from each of the pollinizer cultivars. In addition, $S$-allele genotyping was conducted, and only one pollinizer, 'Anna', was identified as being semicompatible with 'Ingeborg', whereas all other pollinizers were fully compatible. 'Clara Frijs' and 'Belle lucrative' were identified as the most efficient pollinizers probably because these cultivars were abundant compared with all other pollinizers within all, but one of the examined orchards. Higher yields could not be attributed to a particular pollinizer, and genetic effects associated with the triploid nature of 'Ingeborg' are most likely implicated as a cause behind the low and variable yield of this cultivar.

BP 10273 pear ('Conference' $\times$ 'Bonne Louise') was bred at SLU Balsgård (Swedish University of Agricultural Sciences), and after evaluation in Western Norway, it was named 'Ingeborg' in 1994 (Hjeltnes and Ystaas, 1993). This cultivar has become the most widely planted commercial pear variety grown in Norway, including the Hardanger district, western Norway. 'Ingeborg' is a triploid $(3 x)$ and is believed to be the result of fertilization of an unreduced diploid $(2 n)$ egg cell from 'Conference' with a haploid $(n)$ pollen cell from 'Bonne Louise' (Sehic et al., 2012). Although 'Ingeborg' possesses good pomological traits that are highly desirable to Norwegians, fruit set and subsequent yields of this cultivar tend to be erratic and significantly lower than other pear varieties grown in Norway (Meland and Frøynes, 2014).

Yields vary significantly between different orchards in the Hardanger region within any one growing season and parthenocarpy may play a role. Seeds extracted from 'Ingeborg' fruits are frequently underdeveloped. Triploids typically have low fertility due to a reproductive barrier whereby three sets of chromosomes cannot be divided evenly during meiosis yielding unbalanced segregation of chromosomes (Phillips et al., 2016).

Triploids are typically highly infertile; however, limited fertility and seed production can result from the formation of apomictic embryos or through the union of aneuploid or unreduced gametes (Ramsey and Schemske, 1998).

It should be noted that pears, which are auto-incompatible, may have seeds even if they are self-pollinated. Nyéki et al. (1998) found that even during self-pollination, pears can bear fruits, which are a) entirely seedless (parthenocarpic), or b) the seeds were empty or flat without any viable germination, or c) some viable seeds developed at a low rate $(0.5 \%$ to $2 \%)$ in addition to empty seeds. Incompletely formed seeds, low seed number per fruit, or both have reduced sink strength (Weinbaum et al., 2001), which results in lower fruit weight and decreased yields.

Self-fertilization in European pears (Pyrus communis L.), similar to other fruit species of the Rosaceae family, is prevented by gametophytic self-incompatibility (Crane and Lewis, 1942). Consequently, interplanting of suitable pollinizer genotypes in pear orchards is essential for fertilization of the ovules, which in itself is necessary for a successful set of an optimum crop load (Webster, 2002). Identifying cross-compatible pear cultivars is traditionally accomplished with testcrosses and more recently using polymerase chain reaction (PCR) based $S$-genotyping (Mota et al., 2007; Quinet et al., 2014; Sanzol, 2009). However, planting cross-compatible pollinizers, which have coincidental flowering time overlap with the main commercial cultivar, does not always guarantee consistently high yields. In addition, environmental variables, such as rainfall, temperature, and cloud cover, may also negatively affect pollinators and the effective pollination period (EPP) (Sanzol and Herrero, 2001). EPP is defined as the difference between the ovule longevity minus the time between pollination and fertilization (Williams, 1965). Because of generally unfavorable environmental conditions for pear pollination during the Nordic spring, 'Ingeborg' orchards have been established using multiple pollinizer cultivars. Despite this, yields are often low and erratic in some 'Ingeborg' orchards in Hardanger, Norway, and this requires further investigation to identify which of the pollinizers is the most effective, both in high and poor yielding orchards.

Determining pollen compatibility of individual pollinizers may be accomplished by 
genotyping progeny plants produced by germinating seeds extracted from pear fruits of the main commercial cultivar and using the obtained molecular data to identify the male parent. However, the occurrence of aneuploid seedlings with poor viability, frequent among triploids (Zhang and Park, 2009) such as 'Ingeborg', makes the above procedure impractical. Consequently, genetic analyses should be performed on the pear seeds themselves instead of the progeny plants. The seedlings that are produced from seeds will be primarily aneuploids because of unbalanced chromosome segregation in meiosis (Brownfield and Kohler, 2011) with poor viability due to the triploid nature of 'Ingeborg'. However, limited number of progeny from maternal triploids could also be diploids (generational reversion) and tetraploids (fertilization from unreduced gametes from one or both parents) (Phillips et al., 2016).

Microsatellite markers or simple sequence repeats (SSRs) have proven efficient in parent-offspring analyses on pear (Kimura et al., 2003). Although a comparative study has shown that the identification of a highly informative set of single-nucleotide polymorphism (SNP) from a large panel showed significantly more accurate individual genetic assignment compared with the combination of SSR loci (Glover et al., 2010), Moore et al. (2014) found that microsatellite markers are accurate genetic markers for genetic assignment, especially in combination with informative SNPs. In the case of plant parentage, pollination and dispersal analyses, and microsatellites with their various limitations remain an important genetic marker (Ashley, 2010). In addition, there are several readily available microsatellite markers at present, developed from either apple (Gianfranceschi et al., 1998; Liebhard et al., 2002) or pear (FernándezFernández et al., 2006), that can be used in the genetic analyses of European pear genotypes.

In this study, pollination efficacy of several commonly used 'Ingeborg' pollinizers in the Hardanger region was investigated using microsatellite markers. To examine the causes of fertilization between Ingeborg vs. all pollinizer cultivars, molecular analyses of $S$ alleles were performed.

\section{Materials and Methods}

The environmental conditions in Ullensvang, a municipality of Hardanger, Norway's biggest fruit producing region, during flowering were conducive to pollination of

Received for publication 21 July 2017. Accepted for publication 31 Oct. 2017

This study was funded by the Research Council of Norway, project "Increased production volume and consumers' satisfaction of Norwegian pears." ${ }^{1}$ Corresponding author. E-mail: mekjell.meland@ nibio.no.

This is an open access article distributed under the CC BY-NC-ND license (http://creativecommons. org/licenses/by-nc-nd/4.0/).
'Ingeborg' in 2014 and 2016 (Table 1). Because of the unfavorable climatic conditions in 2015 [low minimum temperatures $\left(<7.3{ }^{\circ} \mathrm{C}\right)$ and prolonged heavy rainfall during bloom] that contributed to the low fruit set and insufficient even for research sampling, this year was excluded. Dates of first bloom (BBCH 60), full bloom (80\% of blossoms open), and petal fall (80\%) (Jackson and Looney, 1999) for 'Ingeborg' in six commercial orchards as well as for five pollinizer cultivars during 2014 and 2016 are presented in Table 2, confirming that there was sufficient overlap between all pollinizers and 'Ingeborg' in both 2014 and 2016. At harvest, 50 randomly sampled 'Ingeborg' fruit were gathered from each of the six commercial orchards. Fruits were cut open and all pear seeds were extracted. Orchard size, yield, and age of the six different orchards are presented in Table 3. Pear producers did not provide beehives for pollination, but neighboring farms that are growing cherries and plums are renting beehives for pollination. The distance between some pear orchards and these beehives was $100 \mathrm{~m}$ and more.

Molecular and phenology analyses. Tissue samples (leaves) for DNA analyses were collected in the Spring of 2014 from a single tree of the main commercial cultivar (Ingeborg) and from pollinizer genotypes ('Clara Frijs', 'Herzogin Elsa', 'Anna', 'Colorée de Juillet', and 'Belle lucrative') present in the analyzed orchards. The genomic DNA was isolated from 70 to $80 \mathrm{mg}$ of leaf powder using the CTAB method (Cullings, 1992; Doyle and Doyle, 1987). Extraction and isolation of genomic DNA from pear seeds were conducted according to Padmalatha et al. (2008). As it was impossible to obtain enough high-quality DNA from a single seed for the genetic characterization, well developed seeds collected from each individual orchard were mixed and ground together to obtain a single homogenous sample.

Twelve SSR primer pairs (Table 4) were chosen based on their polymorphism observed in a previous study on European pears (Gasi et al., 2013). All PCR reactions were carried out in accordance with the protocol described by Gasi et al. (2013). Amplification products were separated on an ABI 310 automated sequencer (Applied Biosystems, Foster City, CA). A PCR product $(1 \mu \mathrm{L})$ was added to a master mix containing $9 \mu \mathrm{L}$ of deionized formamide and $0.5 \mu \mathrm{L}$ GeneScan350 Rox size-standard (Applied Biosystems). Samples were heated at $95{ }^{\circ} \mathrm{C}$ for $5 \mathrm{~min}$ and immediately cooled down on ice. SSR profiles were scored using GeneMapper Software ID v3.2 (Applied Biosystems). $S$-genotyping of cultivars for $S 1-S 24$ based on a PCR approach was performed using consensus and allele specific primers published by Sanzol (2009), applying PCR protocols detailed in the same study. Flowering dates (beginning of flowering, full bloom, and petal fall) were recorded for each orchard during 2014 and 2016 to determine the flowering overlap between the main commercial cultivar and the pollinizers.
Biostatistical analyses. The number of different alleles and gene diversity corrected for the sample size (Nei, 1987) were calculated for the main commercial cultivar and its pollinizers as well as for the seeds collected in 2014 and 2016 using SPAGeDI 1.3 (Hardy and Vekemans, 2002). To test if there was a significant difference in number of alleles and gene diversity among the analyzed seeds, between the two seasons, a paired-samples $t$ test was used.

As the seed samples from each single orchard were mixed and ground together, they represent a group of genotypes and not individual offspring; an assignment or exclusion of individuals (Rannala and Mountain, 1997) within the GeneClass 2 software (Piry et al., 2004) was conducted to identify the pollen contribution of each potential pollinizer. The purpose of the genetic assignment is to assign or exclude reference group as the origin individuals on the basis of multilocus genotype data (Piry et al., 2004). We have implemented the Bayesian approach as it has been described by Rannala and Mountain (1997). It included calculation of relative scores with $-\log$ values of the likelihoods without Monte Carlo resampling algorithms.

\section{Results and Discussion}

Pollinator activity may be adversely affected by low temperatures and excessive rainfall during bloom (Scorza et al., 2013). Excessive rainfall may also hinder the diffusion of floral nectar scent (Yan et al., 2016). Temperature also has a major effect on stigmatic receptivity (Hedhly et al., 2003), ovule longevity (Cerovic et al., 2000), pollen germination, and pollen tube growth (Delph et al., 1997).

In 2014 and 2016, temperatures were conducive to pollination and fruit set, and there was negligible rainfall during the bloom periods (Table 1). The average temperature measured during the 'Ingeborg' flowering was higher in $2014\left(13.1^{\circ} \mathrm{C}\right)$ than in 2016 $\left(11.4{ }^{\circ} \mathrm{C}\right)$. However, higher post bloom temperatures, which can significantly influence the decrease of fruit set in pear (Tromp and Borsboom, 1994), were recorded in 2016. As a matter of fact, the average temperature during the 7-d post bloom period in 2014 was $11.1^{\circ} \mathrm{C}$ (with a maximum daily temperature of $19.2{ }^{\circ} \mathrm{C}$ ), whereas in 2016 , it was $14.0^{\circ} \mathrm{C}$ (with a maximum daily temperature of $\left.25.5^{\circ} \mathrm{C}\right)$.

Twelve primer pairs managed to amplify 45 distinct alleles among the main commercial cultivar, pollinizers, and 'Ingeborg' seeds collected in 2014 and 2016 (Table 5). The average number of alleles per locus detected in 2016 (2.25) was significantly lower than the values obtained for the seeds in 2014 (2.75) (paired samples $t=-2.57 ; P<$ $0.05)$. A difference among the seasons was also noted for the gene diversity values $(0.52$ and 0.50 , respectively); however, it was not statistically significant. The higher number of alleles detected for the 'Ingeborg' seeds in 2014 indicates a pollen contribution from 
Table 1. Daily minimum, maximum and average temperatures $\left({ }^{\circ} \mathrm{C}\right)$, and precipitation $(\mathrm{mm})$ of Ullensvang, Norway, during flowering in 2014 through 2016 . Dates of flowering for pear cultivar Ingeborg are bolded. https://lmt.bioforsk.no/agrometbase/getweatherdata_new.php?weatherStationId=54.

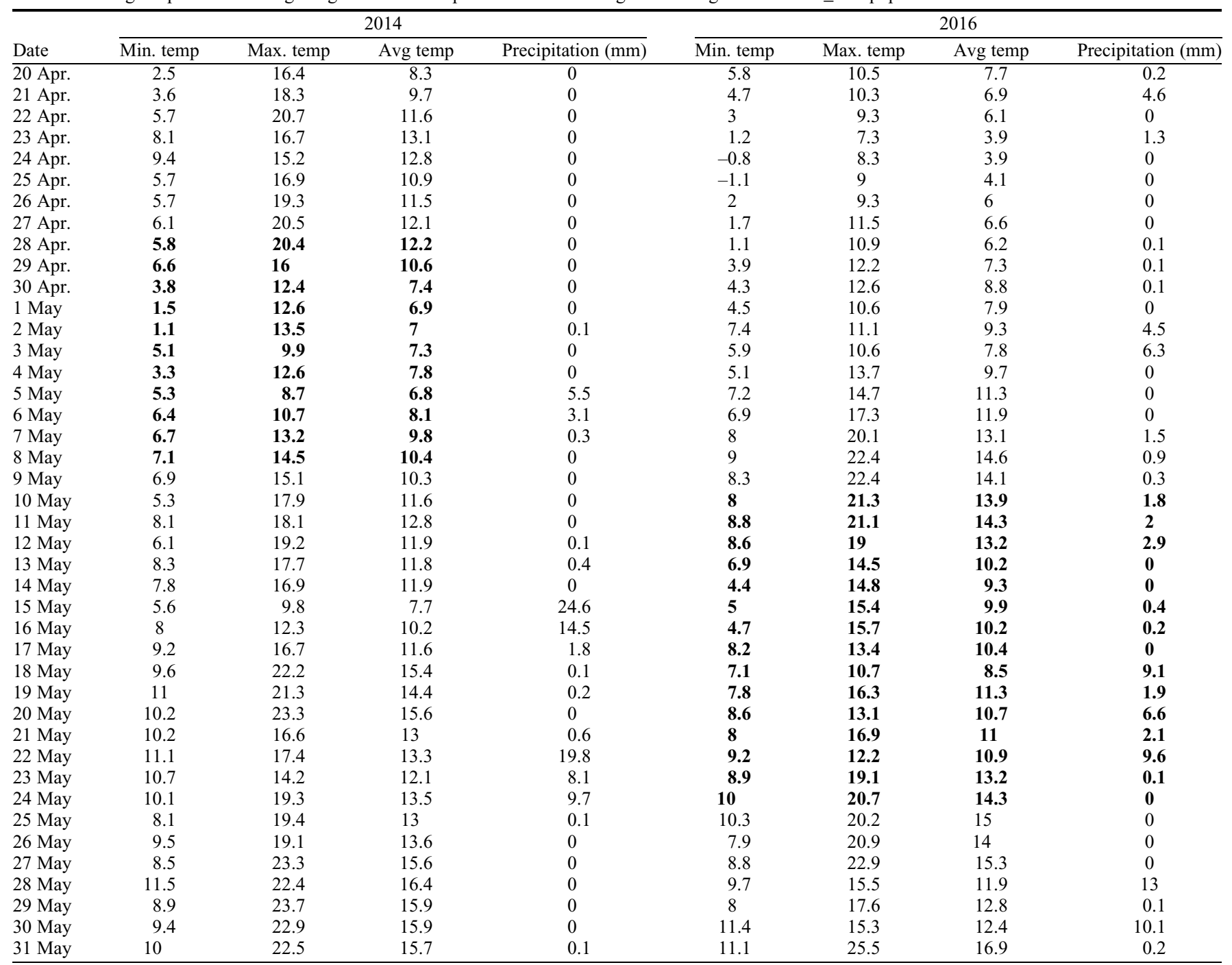

Table 2. Dates of first bloom, full bloom ( $80 \%$ of flowers open), and end of flowering ( $80 \%$ petals fallen) for 'Ingeborg' and pollinizer pear cultivars in Ullensvang, Norway, in 2014 and 2016.

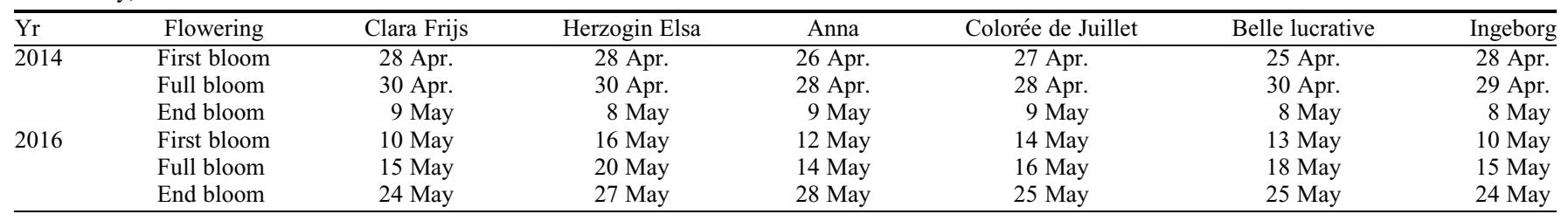

a more diverse set of donors (different pollinizer cultivars). Considering that the same pollinizers were used in both seasons and that the flowering period was overlapping in both years, the differences in pollen contribution between the seasons may have at least partially been influenced by the presence of higher number of insects (pollinators) during warm days in the period of 'Ingeborg' flowering in 2014. The decrease in fruit set might explain the overall decrease in the diversity of alleles detected among the pear seeds and between the 2 years. The potential negative effect of higher post bloom temperatures in 2016 (with $4 \mathrm{~d}$ maximum temperatures above $20{ }^{\circ} \mathrm{C}$ ) than 2014 could also have contributed to lower fruit set in 'Ingeborg', which was selected for cultivation in cooler climates.

In five of the six farms, pollen contribution ratio was very close or almost identical between seasons (Table 6). Farm 4 was the main exception where the pollen contribution in 2014 season was much more evenly distributed between two of the pollinizer genotypes (59\% 'Herzogine Elsa' and $39 \%$ 'Clara Frijs'), whereas in 2016, 'Clara Frijs' was the overwhelmingly dominant pollen donor. The reason for this is that 'Herzogine Elsa' in 2014 and 'Clara Frijs' in 2016 exactly overlapped their flowering with 'Ingeborg' and thus became a main pollen donor.
Overall, pollinizer 'Clara Frijs' was identified as the dominant pollen donor in four of the six orchards analyzed through the gene assignment analyses. This was somewhat expected, considering that this pollinizer cultivar is the most abundant by number in these orchards (Table 3). Also, 'Clara Frijs' had a good time overlap with respect to full bloom coinciding with 'Ingeborg' in both 2014 and 2016 (Table 2). In one of the two remaining orchards, 'Belle lucrative' was the main pollinizer cultivar and was identified to be the overwhelmingly dominant pollen donor in these orchards through the gene assignment analyses. However, on farm 6, even though 'Clara Frijs' was the most 
Table 3. Farm number, orchard size, year of planting, yield of 'Ingeborg' trees in 2014 and 2016, and number of pollinizer cultivars present in six orchards included in the study. Planting density farm 1-5: $1 \times 4 \mathrm{~m}$, farm 6: $3 \times 5 \mathrm{~m}$.

\begin{tabular}{|c|c|c|c|c|c|c|c|c|c|}
\hline \multirow[b]{2}{*}{ Farmer } & \multirow{2}{*}{$\begin{array}{l}\text { Orchard } \\
\text { size (ha) }\end{array}$} & \multirow{2}{*}{$\begin{array}{c}\text { Yr of } \\
\text { planting }\end{array}$} & \multirow{2}{*}{$\frac{\text { Ingeborg yield }\left(\mathrm{t} \cdot \mathrm{ha}^{-1}\right)}{2014}$} & \multirow{2}{*}{$\frac{\text { Ingeborg yield }\left(\mathrm{t} \cdot \mathrm{ha}^{-1}\right)}{2016}$} & \multicolumn{5}{|c|}{ Pollinizer cultivars (no. of trees) } \\
\hline & & & & & Clara Frijs & Herzogin Elsa & Anna & Colorée de Juillet & Belle lucrative \\
\hline Farm 1 & 0.29 & 2000 & 12.1 & 3.61 & 126 & 61 & - & - & - \\
\hline Farm 2 & 0.54 & 2000 & 23.32 & 7.05 & 210 & 80 & - & 29 & - \\
\hline Farm 3 & 0.81 & 2004 & 25.02 & 0.80 & - & - & 60 & 10 & 80 \\
\hline Farm 4 & 1.50 & 2001 & 10.52 & 5.00 & 340 & 180 & 52 & - & - \\
\hline Farm 5 & 0.22 & 2001 & 10.15 & 11.25 & 60 & 30 & 10 & - & - \\
\hline Farm 6 & 0.51 & 2005 & 7.97 & 5.09 & 94 & 44 & 15 & $3^{z}$ & $6^{\mathrm{z}}$ \\
\hline
\end{tabular}

${ }^{\mathrm{z}}$ Large, old trees from neighboring orchard.

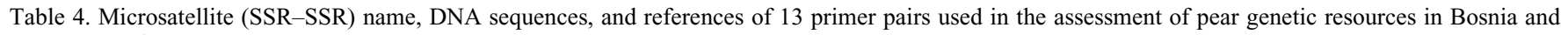
Herzegovina.

\begin{tabular}{|c|c|c|c|}
\hline SSR name & Forward primer & Reverse primer & Reference \\
\hline$\overline{\mathrm{CH}} 02 \mathrm{~b} 10$ & CAAGGAAATCATCAAAGATTCAAG & CAAGTGGCTTCGGATAGTTG & Gianfranceschi et al. (1998) \\
\hline $\mathrm{CH} 03 \mathrm{~g} 07$ & AATAAGCATTCAAAGCAATCCG & TTTTTCCAAATCGAGTTTCGTT & Liebhard et al. (2002) \\
\hline EMPc117 & GTTCTATCTACCAAGCCACGCT & CGTTTGTGTGTTTTACGTGTTG & Fernández-Fernández et al. (2006) \\
\hline $\mathrm{CH} 05 \mathrm{e} 03$ & CGAATATTTTCACTCTGACTGGG & CAAGTTGTTGTACTGCTCCGAC & Liebhard et al. (2002) \\
\hline $\mathrm{CH} 02 \mathrm{c} 06$ & TGACGAAATCCACTACTAATGCA & GATTGCGCGCTTTTTAACAT & Gianfranceschi et al. (1998) \\
\hline EMPc11 & GCGATTAAAGATCAATAAACCCATA & AAGCAGCTGGTTGGTGAAAT & Fernández-Fernández et al. (2006) \\
\hline $\mathrm{CH} 03 \mathrm{~d} 12$ & GCCCAGAAGCAATAAGTAAACC & ATTGCTCCATGCATAAAGGG & Liebhard et al. (2002) \\
\hline $\mathrm{CH} 02 \mathrm{c} 11$ & TGAAGGCAATCACTCTGTGC & TTCCGAGAATCCTCTTCGAC & Liebhard et al. (2002) \\
\hline $\mathrm{CH} 01 \mathrm{~d} 03$ & CCACTTGGCAATGACTCCTC & ACCTTACCGCCAATGTGAAG & Liebhard et al. (2002) \\
\hline $\mathrm{CH} 01 \mathrm{f07a}$ & СССТАCACAGTTTCTCAACCC & CGTTTTTGGAGCGTAGGAAC & Liebhard et al. (2002) \\
\hline $\mathrm{CH} 04 \mathrm{e} 03$ & TTGAAGATGTTTGGCTGTGC & TGCATGTCTGTCTCCTCCAT & Liebhard et al. (2002) \\
\hline $\mathrm{CH} 01 \mathrm{~d} 09$ & СССТТСАТТСАСАТТTССАG & GCCATCTGAACAGAATGTGC & Liebhard et al. (2002) \\
\hline
\end{tabular}

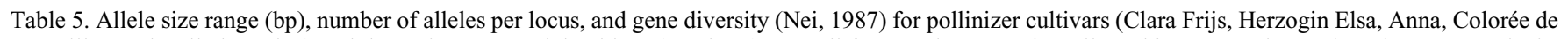
Juillet, and Belle lucrative) and the main commercial cultivar (Ingeborg), as well for 'Ingeborg' seeds, collected in 2014 and 2016 based on 12 SSR loci.

\begin{tabular}{|c|c|c|c|c|c|c|c|c|c|}
\hline \multirow[b]{2}{*}{ Locus code } & \multicolumn{3}{|c|}{ Pollinizers and 'Ingeborg' seeds } & \multicolumn{3}{|c|}{ 'Ingeborg' seeds 2014} & \multicolumn{3}{|c|}{ 'Ingeborg' seeds 2016} \\
\hline & Size range $(b p)$ & No. of alleles & $\mathrm{He}$ & Size range $(b p)$ & No. of alleles & $\mathrm{He}$ & Size range $(b p)$ & No. of alleles & $\mathrm{He}$ \\
\hline$\overline{\mathrm{CH}} 02 \mathrm{~b} 10$ & $120 / 154$ & 5 & 0.80 & $126 / 154$ & 2 & 0.53 & $126 / 154$ & 2 & 0.55 \\
\hline $\mathrm{CH} 03 \mathrm{~g} 07$ & $226 / 258$ & 4 & 0.77 & $226 / 258$ & 3 & 0.67 & $226 / 258$ & 3 & 0.62 \\
\hline EMPc117 & $97 / 129$ & 5 & 0.80 & $97 / 129$ & 4 & 0.77 & $113 / 129$ & 3 & 0.67 \\
\hline $\mathrm{CH} 05 \mathrm{e} 03$ & $164 / 184$ & 2 & 0.17 & 164 & 1 & 0.00 & 164 & 1 & 0.00 \\
\hline $\mathrm{CH} 02 \mathrm{c} 06$ & $130 / 156$ & 4 & 0.68 & $130 / 156$ & 3 & 0.67 & $130 / 156$ & 3 & 0.67 \\
\hline EMPc11 & $136 / 148$ & 3 & 0.44 & $138 / 148$ & 2 & 0.17 & $138 / 148$ & 2 & 0.17 \\
\hline $\mathrm{CH} 03 \mathrm{~d} 12$ & $107 / 123$ & 2 & 0.41 & $107 / 123$ & 2 & 0.41 & $107 / 123$ & 2 & 0.55 \\
\hline $\mathrm{CH} 02 \mathrm{c} 11$ & $213 / 239$ & 4 & 0.74 & $213 / 239$ & 4 & 0.68 & $213 / 237$ & 2 & 0.55 \\
\hline $\mathrm{CH} 01 \mathrm{~d} 03$ & $135 / 149$ & 4 & 0.65 & $135 / 147$ & 3 & 0.62 & $135 / 147$ & 2 & 0.55 \\
\hline $\mathrm{CH} 01 \mathrm{f} 07 \mathrm{a}$ & $174 / 190$ & 5 & 0.82 & $174 / 190$ & 4 & 0.77 & $180 / 190$ & 3 & 0.67 \\
\hline $\mathrm{CH} 04 \mathrm{e} 03$ & $178 / 202$ & 2 & 0.41 & $178 / 202$ & 2 & 0.30 & $178 / 202$ & 2 & 0.55 \\
\hline CH01d09 & $133 / 157$ & 5 & 0.79 & $143 / 155$ & 3 & 0.59 & $143 / 155$ & 2 & 0.53 \\
\hline Mean & & 3.75 & 0.62 & & 2.75 & 0.52 & & 2.25 & 0.50 \\
\hline
\end{tabular}

abundant pollinizer, 'Belle lucrative' was identified as the dominant pollen donor. In fact, 'Belle lucrative' was not even planted as a pollinizer in this orchard; however, several old large trees were present on the neighboring farm. The results obtained are conclusive and indicate that 'Belle lucrative' should be considered as an effective pollinizer in addition to 'Clara Frijs'.

$S$-genotyping of 'Ingeborg' revealed that this cultivar possesses the following three $S$ alleles: $S 102, S 108$, and $S 121$, labeled in accordance with the numeration proposed by Goldway et al. (2009). Considering 'Ingeborg', parent cultivar 'Conference' possesses $S 108$ and $S 121 S$ alleles (Sanzol, 2009), whereas the other parent 'Bonne Louise' possesses $S 101$ and $S 102 S$ alleles (Sanzol and Robbins, 2008), and the obtained $S$ allele profile confirms the conclusion by Sehic et al. (2012) that 'Ingeborg' is derived from an unreduced 'Conference' egg cell being fertilized by a haploid pollen cell from 'Bonne Louise'. The results of $S$-genotyping obtained for the five pollinizer cultivars revealed that only 'Anna' possesses an $S$ allele already present in 'Ingeborg' (S108), making it a semicompatible pollinizer (manuscript is in press). The results of the $S$-genotyping indicate that preferential pollination by individual pollinizers in 'Ingeborg' orchards is not caused by sexual incompatibility.

With regard to yield, 'Clara Frijs' was identified as the dominant pollen contributor in both poor and high producing orchards (Table 3). Furthermore, there were no consistent differences in yield per hectare values between orchards where 'Clara Frijs' was the dominant pollen donor, and the ones where 'Belle lucrative' was identified as the most significant contributor of pollen. Overall, a clear connection between the specific pollinizer and subsequent yield could not be made. Conversely, yield per hectare calculated for each farm was more than double in 2014 compared with 2016. Year-to-year fluctuations in pear blooming, which ultimately affect pollination, fruit set, and crop yield, are known to be affected by prebloom temperature regimes in combination with the climatic condition of the previous season and are also possibly related with bud dormancy (Wertheim and Schmidt, 2005). Although this is a trait common for pear cultivars, 'Ingeborg' fruit set and yield seem to be especially affected depending on season and possibly microclimate, as shown by stark differences in yield between orchards in the same region. Furthermore, Sanzol et al. (2003) demonstrated clearly that asynchronous maturation of the both stigmas and ovules within a single ovary in the same pear flower can occur and varies between years. This probably means that EPP is long enough to ensure the pollination and fertilization in pears. According to Sanzol et al. (2003), this aspect is even more pronounced in populations where pollinator efficiency is low, unreliable pollination conditions exist, or both. This certainly appears to be the case in the Hardanger region. 
Table 6. Pollen contribution of individual pollinizer cultivars in each of the farms included in this study, estimated using gene assignment analyses.

\begin{tabular}{|c|c|c|c|c|c|c|}
\hline \multirow[b]{2}{*}{ Orchard } & \multirow[b]{2}{*}{ Season } & \multicolumn{5}{|c|}{ ASSIGNMENT-Score $(\%)^{z}$} \\
\hline & & Clara Frijs & Herzogin Elsa & Anna & Colorée de Juillet & Belle lucrative \\
\hline \multirow[t]{2}{*}{ Farm 1} & 2014 & 98.705 & 1.295 & - & - & - \\
\hline & 2016 & 98.961 & 1.039 & - & - & - \\
\hline \multirow[t]{2}{*}{ Farm 2} & 2014 & 99.729 & 0.023 & - & 0.249 & - \\
\hline & 2016 & 99.589 & 0.163 & - & 0.248 & - \\
\hline \multirow[t]{2}{*}{ Farm 3} & 2014 & - & - & - & 0.010 & 99.990 \\
\hline & 2016 & - & - & - & 0.075 & 99.925 \\
\hline \multirow[t]{2}{*}{ Farm 4} & 2014 & 39.444 & 58.696 & 1.860 & - & - \\
\hline & 2016 & 98.407 & 0.820 & 0.773 & - & - \\
\hline \multirow[t]{2}{*}{ Farm 5} & 2014 & 98.752 & 1.058 & 0.190 & - & - \\
\hline & 2016 & 89.400 & 6.386 & 4.215 & - & - \\
\hline \multirow[t]{2}{*}{ Farm 6} & 2014 & 3.356 & 0.002 & 0.003 & 0.912 & 95.726 \\
\hline & 2016 & 3.252 & 0.005 & 0.017 & 0.276 & 96.449 \\
\hline
\end{tabular}

${ }^{\mathrm{z}} \mathrm{X} \%$ of progeny were derived from $\mathrm{Y}$ pollenizer culitvar.

The most notable difference between 'Ingeborg' and other pear cultivars, which display higher and more regular yields in Norwegian conditions, is its triploid nature, the effect of which, on the fruit set, needs to be investigated further. Fertilization with unreduced gametes, apomixis, and pseudogamy were documented in triploid-derived embryos/offspring but were relatively uncommon. The considerable reduction in female fertility of some triploid selections coupled with the limited production of primarily aneuploid progeny provides desirable options for new infertile flowering pears to prevent or reduce reseeding and naturalizing (Phillips et al., 2016).

\section{Conclusions}

'Clara Frijs' was found to be the main pollinizer cultivar, in all, but two of the orchards analyzed. This was mainly a function of the number of trees planted when compared with other pollinizer cultivars. 'Anna' shared one incompatible $S$ allele with 'Ingeborg', making it less suitable as a pollinizer. It is important to note that in one of the orchards analyzed, pollen contribution was distributed more evenly across several pollinizers in 2014, compared with 2016 . This is probably because of a smaller overlap between the full bloom date among 'Ingeborg' and its pollinizers in 2016 and much higher maximum temperatures in post bloom period in 2016. Poor ovule fertilization and low yields in 'Ingeborg' are not caused by sexual incompatibility, and in the light of the present study, it can be concluded that both 'Clara Frijs' and 'Belle lucrative' are efficient pollinizers and should be recommended for future 'Ingeborg' plantings. Finally, future investigations examining the EPP of 'Ingeborg' in relation to temperatures, both minimum and maximum during flowering, could lead to a better understanding of fertilization, which in turn would lead to higher yields under cool mesic Norwegian growing conditions.

\section{Literature Cited}

Ashley, M.V. 2010. Plant parentage, pollination, and dispersal: How DNA microsatellites have altered the landscape. Crit. Rev. Plant Sci. 29:148-161.
Brownfield, L. and C. Kohler. 2011. Unreduced gamete formation in plants: Mechanisms and prospects. J. Expt. Bot. 62(5):1659-1688.

Cerovic, R., D. Ruzic, and N. Micic. 2000. Viability of plum ovules at different temperatures. Ann. Appl. Biol. 137:53-59.

Crane, M.B. and D. Lewis. 1942. Genetical studies in pears. III. Incompatibility and sterility. J. Genet. 43:31-44.

Cullings, K.W. 1992. Design and testing of a plantspecific PCR primer for ecological and evolutionary studies. Mol. Ecol. 1:233-240.

Delph, L.F., M.H. Johannsson, and A.G. Stephenson. 1997. How environmental factors affect pollen performance: Ecological and evolutionary perspectives. Ecology 78:1632-1639.

Doyle, J. and J.L. Doyle. 1987. Genomic plant DNA preparation from fresh tissue - the CTAB method. Phytochem. Bull. 19:11.

Fernández-Fernández, F., N.G. Harvey, and C.M. James. 2006. Isolation and characterization of polymorphic microsatellite markers from $\mathrm{Eu}-$ ropean pear (Pyrus communis L.). Mol. Ecol. Notes 6:1039-1041.

Gasi, F., M. Kurtovic, B. Kalamujic, N. Pojskic, J. Grahic, C. Kaiser, and M. Meland. 2013. Assessment of European pear (Pyrus communis L.) genetic resources in Bosnia and Herzegovina using microsatellite markers. Scientia Hort. 157:74-83.

Gianfranceschi, L., N. Seglia, R. Tarchini, M. Komjanc, and C. Gessler. 1998. Simple sequence repeats for the genetic analyses of apple. Theor. Appl. Genet. 96:1069-1079.

Goldway, M., T. Takasaki, J. Sanzol, M. Mota, A.H. Zisovich, R.A. Stern, and S. Sansavini. 2009. Renumbering the S-Rnase alleles of European pears (Pyrus communis L.) and cloning the S109 Rnase allele. Scientia Hort. 119:417-422.

Glover, K.A., M.M. Hansen, S. Lien, T.D. Als, B. Høyheim, and Ø. Skaala. 2010. A comparison of SNP and STR loci for delineating population structure and performing individual genetic assignment. BMC Genet. 11:2.

Hardy, O.J. and X. Vekemans. 2002. A versatile computer program to analyse spatial genetic structure at the individual or population level. Mol. Ecol. Notes 2:618-620.

Hedhly, A., J.I. Hormaza, and M. Herrero. 2003. The effect of temperature on stigmatic receptivity in sweet cherry (Prunus avium L.). Plant Cell Environ. 26:1673-1680.

Hjeltnes, S.H. and J. Ystaas. 1993. Breeding pears adapted to Scandinavian growing conditions: Screening of 46 advanced pear selections 1985-91. Nor. J. Agr. Sci. 7:29-39.
Jackson, D.I. and N.E. Looney. 1999. Temperate and subtropical fruit production. 2nd ed. CABI Publ. Wallingford, UK.

Kimura, T., Y. Sawamura, K. Kotobuki, N. Matsuta, T. Hayashi, Y. Ban, and T. Yamamoto. 2003. Parentage analysis in pear cultivars characterized by SSR marker. J. Jpn. Soc. Hort. Sci. 72:182-189.

Liebhard, R., L. Gianfranceschi, B. Koller, C.D. Ryder, R. Tarchini, E. Van De Weg, and C. Gessler. 2002. Development and characterization of 140 new microsatellite in apple (Malus $\times$ domestica Borkh.). Mol. Breed. 10:217-241.

Meland, M. and O. Frøynes. 2014. Evaluation of new Norwegian pear cultivars in a Nordic climate. ISHS 12th Pear Symposium, Leuven, Belgium. July 14-18, 2014. p. 56.

Moore, J-S., V. Bourret, M. Dionne, I. Bradbury, P. O'Reilly, M. Kent, G. Chaput, and L. Bernatchez. 2014. Conservation genomics of anadromous Atlantic salmon across its North American range: Outlier loci identify the same patterns of population structure as neutral loci. Mol. Ecol. 23:5680-5697.

Mota, M., L. Tavares, and C.M. Oliveira. 2007. Identification of S-alleles in pear (Pyrus communis L) cv. 'Rocha' and other European cultivars. Scientia Hort. 113:13-19.

Nei, M. 1987. Molecular evolutionary genetics. Columbia University Press, New York, NY.

Nyéki, J., A. Porpáczy, M. Soltész, Z. Szabó, and J. Iváncsics. 1998. Self-fertility of pear varieties conditioned by natural self-pollination (autogamy). Acta Hort. 475:433-434.

Padmalatha, K., K. Jayaram, and M.N.V. Prasad. 2008. A rapid protocol for the isolation of polysaccharide- and polyphenolic-free genomic DNA for RAPD analysis of threatened medicinal plants. Med. Aromat. Plant Sci. Biotechnol. 2:50-53.

Phillips, W.D., T.G. Ranney, D.H. Touchell, and T.A. Eaker. 2016. Fertility and reproductive pathways of triploid flowering pears (Pyrus sp.). HortScience 51:968-971.

Piry, S., A. Alapetite, J.-M. Cornuet, D. Paetkau, L. Baudouin, and A. Estoup. 2004. GeneClass2: A software for genetic assignment and firstgeneration migrant detection. J. Hered. 95:536539.

Quinet, M., S. Kelecom, and A-L. Jacquemart. 2014. S-genotype characterization of 13 north western european pear (Pyrus communis) cultivars. Scientia Hort. 165:1-4.

Ramsey, J. and D.W. Schemske. 1998. Pathways, mechanisms, and rates of polyploid formation in flowering plants. Annu. Rev. Ecol. Syst. 29:467-501.

Rannala, B. and J.L. Mountain. 1997. Detecting immigration by using multilocus genotypes. Proc. Natl. Acad. Sci. USA 94:9197-9201.

Sanzol, J. 2009. Genomic characterization of selfincompatibility ribonucleases in European pear cultivars and development of PCR detection for 20 alleles. Tree Genet. Genomes 5:393-405.

Sanzol, J. and M. Herrero. 2001. The effective pollination period in fruit trees. Scientia Hort. 90:1-17.

Sanzol, J., P. Rallo, and M. Herrero. 2003. Asynchronous development of stigmatic receptivity in the pear (Pyrus communis, Rosaceae) flower. Amer. J. Bot. 90:78-84.

Sanzol, J. and T.P. Robbins. 2008. Combined analysis of $\mathrm{s}$ alleles in European pear by pollinations and PCR based S-genotyping: Correlation between $\mathrm{S}$ phenotypes and S-Rnase genotype. J. Amer. Soc. Hort. Sci. 133:213-224. 
Scorza, R., A.B. Kriss, A.M. Callahan, K. Webb, M. Demuth, and T. Gottwald. 2013. Spatial and temporal assessment of pollen and seed-meidated gene flow rom genetically engineered plum Prunus domestica. PLoS One 8(10):E75291.

Sehic, J., L. Garkava-Gustavsson, F. FernándezFernández, and H. Nybom. 2012. Genetic diversity in a collection of European pear (Pyrus communis) cultivars determined with SSR markers chosen by ECPGR. Scientia Hort. 145:39-45.

Tromp, J. and O. Borsboom. 1994. The effect of autumn and spring temperature on fruit set and on the effective pollination period in apple and pear. Scientia Hort. 60:23-30.

Webster, A.D. 2002. Factors influencing the flowering, fruit set and fruit growth of European pears. Acta Hort. 596:699-709.

Weinbaum, S.A., T.M. DeJong, and J. Maki. 2001. Reassessment of seed influence on return bloom and fruit growth in 'Bartlett' pear. HortScience 36:295-297.

Wertheim, S.J. and H. Schmidt. 2005. Flowering, pollination and fruit set p. 216-239. In: J. Tromp, A.D. Webster, and S.J. Wertheim (eds.). Fundamentals of temperate zone tree fruit production. Backhuys Publishers, Leiden, The Netherlands.

Williams, R.R. 1965. The effect of summer nitrogen on the quality of apple blossom. J. Hort. Sci. 40:31-41.

Yan, J., G. Wang, Y. Sui, M. Wang, and L. Zhang. 2016. Pollinator responses to floral colour change, nectar, and scent promote reproductive fitness in Quisqualis indica (Combretaceae). Scientific Rep. 6:24408.

Zhang, C.H. and S.M. Park. 2009. Aneuploid production from crosses with diploid and triploid in apple tree. H. E. B. 50:203-307. 